$\mathrm{DE}$

M E D I C I N A

T R O P I C A L

$\mathrm{DE}$

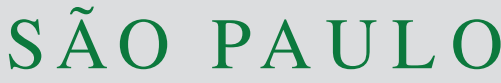

JOURNAL OF THE SÃO PAULO INSTITUTE OF TROPICAL MEDICINE

${ }^{1}$ Universidade Federal de Pernambuco, Laboratório de Imunopatologia Keizo Asami, Setor de Virologia, Recife,

Pernambuco, Brazil

${ }^{2}$ Universidade Federal de Pernambuco, Centro Acadêmico do Agreste, Caruaru, Pernambuco, Brazil

${ }^{3}$ Fundação Oswaldo Cruz, Instituto Aggeu Magalhães, Departamento de Entomologia, Recife, Pernambuco, Brazil

${ }^{4}$ Fundação Oswaldo Cruz, Instituto Aggeu Magalhães, Departamento de Virologia e Terapia Experimental, Recife, Pernambuco, Brazil

${ }^{5}$ Universidade Federal de Santa Maria, Departamento de Medicina Veterinária Preventiva, Setor de Virologia, Santa Maria, Rio Grande do Sul, Brazil

Correspondence to: José Valter Joaquim Silva Júnior

Universidade Federal de Santa Maria, Departamento de Medicina Veterinária Preventiva, Setor de Virologia,

Av. Roraima $n^{\circ} 1000$, Cidade Universitária,

Bairro Camobi, CEP: 97105-900, Santa

Maria, RS, Brazil

E-mail: josevalterjsilvajr@gmail.com

Received: 4 December 2018

Accepted: 16 January 2019

\section{Arbovirus control: what is the (real) stone in the way?}

\section{Dear Editor}

Infections by arboviruses are a historic public health problem in tropical and subtropical countries and territories ${ }^{1}$. More recently, several factors, such as climate changes and globalization, have contributed to the increase of the distribution of arboviruses and (re-)emergence of some viral species in many areas, including temperate regions ${ }^{2,3}$. As a result, many universities, research centers and institutes around the world have the mosquito-borne viral diseases as major research object. Interestingly, the attention, investment and scientific rigor given to the subject sometimes have secondary importance and factors of non-scientific order contribute to widening the gap between research and population.

Regarding the reduction of mosquito vectors, various alternative measures, such as biocontrol strategies, have been strongly suggested to overcome the toxicity to non-target organisms and resistance mechanisms triggered by chemical insecticides. For example, larvicidal fish, such as Gambusia affinis and Poecilia reticulata, and copepods, such as Mesocyclops thermocyclopoides and M. longisetus, have been successfully used to control Aedes aegypti populations and decrease the number of Dengue virus (DENV) infections ${ }^{4}$.

Despite the optimistic results of these and others related-interventions, it is necessary to evaluate their sustainability in different environments, long-term effects, influence on the ecological balance and on the interaction between target and nontarget species. The time and infrastructure required for the analysis, in addition to possibility of unsatisfactory results, require more cautious conclusions about the real contribution of vector control measures. Indeed, in this perspective, the relative distance between research and society is scientifically justified.

About the mass immunization, the development of some vaccine strategies is also hindered by scientific obstacles associated to molecular characteristics and pathogenesis of the target viral species. Multiple DENV serotypes and the possibility of antibody-dependent enhancement of infection have been an old problems for the development of a safe DENV vaccine. The fine balance between immunogenicitysafety and the development of a safe vaccine for the fetus are the most important concerns for the chikungunya and Zika vaccines, respectively ${ }^{1}$. Historically, however, the gap between vaccine development and immunization action has been supported by other criteria, notably less scientific.

The yellow fever vaccine, for instance, although developed between 1930 and 1940, has not yet been used as an effective disease prevention measure in many regions of South America and Africa. In recent literature, vaccine coverage for countries at risk for yellow fever ranged from $0 \%$ in parts of Central and Eastern Africa to $100 \%$ in part of the Amazonas State (Brazil) ${ }^{5}$. In Africa, risk areas for disease with lack of vaccination coverage included large part of Central and Eastern Africa and parts of Nigeria, Niger, Sierra Leone, Liberia and Guinea-Bissau ${ }^{5}$. In Brazil, only in 2018 an immunization plan for the whole country ${ }^{6}$ was established. In the same trend, the anti-dengue vaccine (CYD-DTV vaccine, ChimeriVax-Dengue/ Dengvaxia $^{\circledR}$ ), licensed since 2015 and currently approved in 20 countries, is not yet part of the immunization schedule of many countries where dengue fever is endemic ${ }^{7}$.

In this context, in addition to investing in integrated vector management and/or vaccination strategies for arboviruses, it is also necessary to focus and discuss others factors, probably of economic and political origin, that hamper the implementation 
of satisfactory scientifically measures. Otherwise, why investing funds and knowledge in laboratory practices if, ultimately, criteria that do not meet the scientific requirements seem to be the most important? In the broadest sense, following the verses of the Brazilian poet Carlos Drummond de Andrade (1928): "In the middle of the way had (has) a stone/Had (Has) a stone in the middle of the way" from the Portuguese "No meio do caminho tinha (tem) uma pedra/ Tinha (Tem) uma pedra no meio do caminho"; it is imperative to ask: what is the (real) stone between laboratory and social outcome?!

\section{Thaísa Regina Rocha Lopes ${ }^{1}$ Marcelo Henrique Santos Paiva ${ }^{2,3}$ \\ Pablo Cantalice Santos Farias ${ }^{4}$ José Valter Joaquim Silva Júnior ${ }^{4,5}$}

\section{FINANCIAL SUPPORT}

The authors thank to the Conselho Nacional de Desenvolvimento Científico e Tecnológico, Fundação de Amparo à Ciência e Tecnologia de Pernambuco and Coordenação de Aperfeiçoamento de Pessoal de Nível Superior by the financial support.

\section{REFERENCES}

1. Silva Jr JV, Lopes TR, Oliveira-Filho EF, Oliveira RA, DurãesCarvalho R, Gil LH. Current status, challenges and perspectives in the development of vaccines against yellow fever, dengue, Zika and chikungunya viruses. Acta Trop. 2018;182:257-63.

2. Tabachnick WJ. Climate Change and the arboviruses: lessons from the evolution of the dengue and yellow fever viruses. Annu Rev Virol. 2016;3:125-45.

3. Wilder-Smith A, Gubler DJ, Weaver SC, Monath TP, Heymann DL, Scott TW. Epidemic arboviral diseases: priorities for research and public health. Lancet Infect Dis. 2017;17: e101-6.

4. Benelli G, Jeffries CL, Walker T. Biological control of mosquito vectors: past, present, and future. Insects. 2016;7:E52.

5. Wilder-Smith A. Yellow fever vaccination: estimating coverage. Lancet Infect Dis. 2017;17:1109-11.

6. Brasil. Ministério da Saúde. Vacina de febre amarela será ampliada para todo o Brasil. [cited 2018 Sept 23]. Available from: http:// portalms.saude.gov.br/noticias/agencia-saude/42849-vacinade-febre-amarela-sera-ampliada-para-todo-o-brasil

7. World Health Organization. Revised SAGE recommendation on use of dengue vaccine: 19 april 2018. [cited 2018 Sept 23]. Available from: http://www.who.int/immunization/diseases/ dengue/revised_SAGE_recommendations_dengue_vaccines_ apr2018/en/ 